\title{
A Socio-pragmatic Study of Hedging in Iraqi Arabic
}

\section{Lecturer AkramNadhim Raheem Al Salami (Ph.D)}

(The Islamic University in An Najaf/ Iraq/ College of Education/ Department of English)

\section{Lecturer Saeed Mahdi Abdul Raheem (M.A)}

(Ministry of Education/ General Directorate in An Najaf/Iraq)

\section{ABSTRACT}

Among the different types of linguistic means are the expressions of fuzziness and uncertainty which are used by speakers widely. These types of expressions are called hedges. Many scholars have studied this phenomenon from both semantic and pragmatic perspectives. Hyland (1998:1) defines hedges as Devices used to convey tentativeness to reflect uncertainty. Lakoff, Brown and Levinson (1987) develop different perspectives on the basis of speech act theory and consider hedges as strategies for minimizing the threat to face.Hedges are considered a very important part in languages and they play an effective role in communication. Hedges are universal, that is, they are found in all languages and according to this type of expressions Many Iraqi people use them in their daily speech and we are unaware of the use of this phenomenon in Iraqi language. e.g / what are the functions, the strategies or the types that are used the most.To The best of the researcher's knowledge, hedges have not been dealt with in Iraqi Arabic. Hence, this study addresses the following questions:How do Iraqi people use hedges? And What type of hedges do Iraqi people use the most?This study aims atthe identification of the pragmatic types of hedging, shedding light on the functions of such a pragmatic phenomenon. Therefore, it is hypothesized that It is hypothesized that: hedging is used in Iraqi Arabic serving identifiable pragmatic functions. As far as the use of hedging is concerned, the present study is limited to the use of hedges in Iraqi Arabic. To serve the aims of the study, a data including a number of educated and uneducated Iraqis is chosen is selected for this purpose.

\section{Keywords:}

Hedging; types of hedging; pragmatic functions; strategies of hedging;

Article Received: 18 October 2020, Revised: 3 November 2020, Accepted: 24 December 2020

\section{Introduction}

The concept of hedging was firstly put forward by the American linguist George Lakoff (1972:485) Who defined it as "a word or group of words whose Job is to make things fuzzier or less fuzzy". However, different schools made different definitions of the same pragmatic phenomenon. Hyland (1998:23) suggests that hedge is "any linguistic means used to indicate either a lack of a complete commitment to the truth of a proposition or a desire not to express that commitment categorically ". In addition, Thompson (2001: 7) claimed that hedge is a term or an expression of uncertainty. Fraser (2010:143) also defined it as words or expressions that come in the form of models, tag questions, fillers or uncertainty markers that can attenuate the Force of the speech acts and express ranges or levels of uncertainty towards the propositions in the speech. George yule (2014: 131) mentioned hedges and defined it as "a word or phrase used to indicate that you are not really sure that what you are saying is sufficiently correct or complete".

\section{Definitions of Hedging}

In most of the recent work relating to hedging, many scholars have analyzed hedging with an eye on the communication situation, and specially to show its effect in face to face communication .Addressing hedging in news writing, ,zuck and zuck(1085 cited in verttala, 2001:172) defined hedging as " The process whereby The author "reduce the strength of what he is writing. 
Farthermore, in across -linguistic treatment of hedging as a strategy of "saying less than one means".Hedging appears in more than one analysis relating to pragmatics whose main functions are to modify the speakers' responsibility for the truthfulness of utterances, and to modify the definiteness of utterances or its information.

Brown and Levinson (1987:50) State that "hedging is a particle word, phrase that modifies the degree of membership that is private, or true than perhaps might be expected". However, Holmes (1984:4) demonstrates that there are a variety of linguistic means by which a speaker can signal a wish not to impose that is to say, hedges of utterance. While Hubler produce the strength of (1983:10) starts from the presumption that in language use "there are opposition to all sentences ", the use of the hedging phenomenon provides an opportunity to prepare for possible apposition.This illustrates that Hubler takes the reasons underlying the use of hedges to be pragmatic by nature in so far as he emphasized the international aspects underlying hedging. So since hedging is closely related to the attitude a speaker has towards the proposition expressed and inferring the speaker's propositional attitude is in

fact a pragmatic process.

\section{The Pragmatic Classification of Hedges}

In this study, hedges are classified into four major types. the researcher put together all the types which are considered hedges and that have been mentioned and classified by different scholars. this classification is the eclectic modal that is used

in chapter three in analyzing the collected data. Starting with H.F.prince et . al., they (1982:29) state that Hedges are very important means that are frequently used as expressions of uncertainty or as a very important field in fuzzy language. They classified hedges into two kinds: Approximators and shields.

\subsection{Approximators}

Approximators are the expressions that can either change the meaning of the proposition or provide alternative meaning proposition, but according to different situations. In other words, the original truth condition of the proposition can be affected by approximators sometimes even the meaning of proposition can be changed by them. These Approximators are divided into Adaptors and rounders. (Ibid)

\section{A)Adaptors}

They are regarded as the expressions or the words that express the degree of correctness and clarity, The uncertain tone of the speaker. Some examples about them are as follows:

Sort of, kind of, almost, to some extent, quite, little bit ...... est.

1. e.g. Judging from his daily performance he is a little bit lazy.

In the example above, the original degree of certainty and absoluteness has been changed in accordance with the real situation through using a little bit. (ibid)

\section{B) Rounders}

These expressions indicate that the information or data of something is not precise or accurate, in another words they indicate the inexact preciseness of terms.

Rounds are like :- Approximately, roughly , about, essentially .... etc

2.e.g) The number of victims dying from the tsunami in this area are approximately three million.

The example above shows how the expression "approximately" makes the original accurate data less precise (ibid).

\subsection{Shields}

Shields are words or expressions used to indicate that speakers are not fully sure of the validity of the proposition they reflect, the speakers personal stances without affecting the truth condition.

These shields can be classified into plansibility shields and attribution Shields (ibid)

\section{A) Plansibility shields}

They are used by the speakers to show their own attitude towards a proposition mostly they express speakers uncertainty of the truth value of the proposition. Simply speaking, plansibility shields are ways used to show that the statement is not absolutely right 
They usually include first pronoun and they are like : I think, I guess, I assume, As far as I am concerned etc

3.e.g) as far as I am concerned his proposal is the best of all that we have received.

This example shows us the speakers and uncertainty which is done by using the expression " as far as I am concerned " (ibid).

\section{B) Attribution Shields}

They are terms or expressions used by speakers to express their attitude indirectly and these expressions help the speaker to avoid taking the responsibility if the proposition is false, they include : according to him, as it will not, the possibility will be, someone suggests that,........ etc

4.e.g) it is reported that the original habitat of this kind of deer is in Northern America

In the example mentioned above we see that the speaker expresses his opinion indirectly by using attribution shields like "it is reported that" and this expression helps the speaker to avoid being responsible for the proposition if it was not true (ibid) .

\section{Hedging as a Politeness Device}

Holmes (1988:2) speaks about Hedging and says that it can be expressed through epistemic device.

Also he tackles epistemic modality and treats it as a politeness "difference rather than uncertainty.

"Device which reflects

many other writers (e.g Myers 1989;Hinkel 1997)

considered hedging as one of the negative

politeness strategies which implies distancing

oneself and avoiding imposition on other

For Myers (1989:14), he believes that some of the hedging expressions show that the relationship between the writer and the reader in scientific articles can be interpreted as the politeness marker and not all of them have the role of expressing probability.

So Hedging and politeness are not synonyms, however as Myers points about hedging is a politeness strategy when it's makes a claim, or any other statement, as being provisional, bending acceptance in the literature, acceptance by the community in other words acceptance by the readers (1989:12).

\section{Methodology}

In this chapter the investigation of hedging in Iraqi Arabic will be performed through certain steps. The first one is the collection of data. In this step, the researcher records the daily spontaneous speech and the conversation of the educated and the uneducated Iraqi people by using a tape recorder. The sample may involve .

e.g/ a speech or a conversation between a teacher and his students, father and his son, young boy and an old man or a doctor and his patient and so on.

The second step is the selection of the Iraqi Arabic words and expressions which imply hedges in their meanings.

And then comes the step of analyzing the data this step includes the process of classifying the Iraqi Arabic hedges as ,per the English classification of hedges which is considered the eclectic model of this study and that has been mentioned in chapter two.

\subsection{Data Collection \& Analysis}

This section involves the process of using a tape recorder the researcher recorded over twenty conversations from different Iraqi Arabic Contexts, the expressions which have kind of fuzziness or uncertainty and out of these twenty conversations are almost fifty hedging expressions have been analyzed as mentioned in the table below. The following formula is used to calculate percentages of the hedging types that have been mentioned in the conversations.

A- percentage $=\frac{\text { hedges number }}{50} \times 100 \%$

B- The total number of hedges types which are used $=50$.

Starting with Adapters which are the first type of Approximators hedges three of them has been mentioned in the conversations and one of them is:

e.g) nawean ma $\rightarrow$ kind of. 
The percentage of using this type is $6 \%$.the second type of hedges is Rounders which are the second type of Approximates hedges.

Five of this types have been expressed and one of them is: e.g) taqribaan $\rightarrow$ approximately ).

The percentage of using this type is $10 \%$.the third type is plansibility which is one of the types of shields headges . thirteen of this type have been used in the conversations and one of them is: e.g) hasabeilmi $\rightarrow$ as far as I know .

They represent the type that is used the most, and the percentage of using this type is $26 \%$ so it is the highest among the other types of hedges .

Attribution shields are the fourth type of hedges ten expressions from this type have been mentioned in the conversations, one of them is :

(e.g/ hasab ma madhkur $\rightarrow$ it is reported that)

The percentage of this type $10 \%$. The fifth type is compound hedges and the first of these compound hedges model auxiliary with lexical verb and hedging content .

For example: (sayazhar $\rightarrow$ it would appear)

None of this type has been used and the percentage is $0 \%$.

The sixth type is double hedges it is the second type of compound hedges four of this type have been mentioned one of them is: (e.g/ hadhaihtimalyushir $\rightarrow$ this probably indicates) the percentage of using this type is $8 \%$.

The seventh one is Triple Hedges which are the third type of compound hedges two of them have been used one of them is (e.g/ Ybdw min almaequl an nuftaraddhik $\rightarrow$ It seems reasonable to assume that ) .

The percentage of using this type is $4 \%$.

The eighth type is quadruple hedges they are the fourth type of compound hedges none of them has been used they are like : (e.g) Qadybdwmuatwaqaeneiilaahadin ma dhlk $\rightarrow$ It may appear somewhat speculative that) .

The percentage is $0 \%$ the one before the last type The one before the last type is model auxiliary verbs eight of this type have been mentioned the commonest one is (e.g\yumkin $\rightarrow$ might be) .

The percentage of using this type is $16 \%$.

The last type of hedges that have been used in the conversation is if clause.

Five of them have been mentioned one of them is

(e.g/ iidhasahih $\rightarrow$ if true ). The percentage is $10 \%$ 


\section{Hedges in Iraqi Arabic}

\begin{tabular}{|c|c|c|c|c|c|}
\hline \multicolumn{4}{|c|}{ Hedges Types } & \multirow{3}{*}{$\begin{array}{c}\text { The } \\
\text { number } \\
\text { of } \\
\text { hedges } \\
\text { used }\end{array}$} & \multirow{3}{*}{ p. } \\
\hline \multirow[b]{2}{*}{ No. } & \multirow[b]{2}{*}{ Types } & \multicolumn{2}{|l|}{ Utterances } & & \\
\hline & & Arabic Romanized & $\begin{array}{c}\text { English } \\
\text { translation }\end{array}$ & & \\
\hline 1 & $\begin{array}{c}\text { (Approximators) } \\
\text { Adaptors }\end{array}$ & Nawean ma & Kind of & 3 & $6 \%$ \\
\hline 2 & $\begin{array}{c}\text { (Approximators) } \\
\text { Rounders }\end{array}$ & Taqribaan & Approximately & 5 & $10 \%$ \\
\hline 3 & $\begin{array}{l}\text { (shields) } \\
\text { Plansibility }\end{array}$ & Hasabeilmi & As far as I know & 13 & $26 \%$ \\
\hline 4 & $\begin{array}{l}\text { ( Shields) } \\
\text { Attribution }\end{array}$ & Hasab ma madhkur & $\begin{array}{c}\text { It is reported } \\
\text { that }\end{array}$ & 10 & $20 \%$ \\
\hline 5 & $\begin{array}{c}\text { (shields) } \\
\text { Model auxiliary } \\
\text { with lexical verb } \\
\text { and hedging } \\
\text { content }\end{array}$ & Sayazhar & It would appear & 0 & $0 \%$ \\
\hline 6 & $\begin{array}{c}\text { (shields) } \\
\text { compound } \\
\text { hedges. } \\
\text { A- duble hedges }\end{array}$ & Hadhaaihtimalyushir & $\begin{array}{l}\text { This probably } \\
\text { indicates }\end{array}$ & 4 & $8 \%$ \\
\hline 7 & B-Triple hedges & $\begin{array}{c}\text { Ybdw min almaequl an } \\
\text { nuftaraddhik }\end{array}$ & $\begin{array}{c}\text { It seems } \\
\text { reasonable to } \\
\text { assume that }\end{array}$ & 2 & $4 \%$ \\
\hline 8 & $\begin{array}{l}\text { Quadruple } \\
\text { hedges }\end{array}$ & $\begin{array}{c}\text { Qadybdwmuatwaqaeiilaahadin } \\
\text { ma dhlk }\end{array}$ & $\begin{array}{c}\text { It may appear } \\
\text { somewhat } \\
\text { speculative that }\end{array}$ & $\mathbf{0}$ & $0 \%$ \\
\hline 9 & $\begin{array}{c}\text { Model auxiliary } \\
\text { verbs }\end{array}$ & Yumkin & Might be & 8 & $16 \%$ \\
\hline 10 & If clause & Iida sahih & If true & 5 & $10 \%$ \\
\hline
\end{tabular}

\section{Conclusions}

The study of hedges has drawn much attention from researchers and hedges have showed great

Communication value in many fields however the study of this concept in Iraqi Arabic is of a great significance.

Hence, this study aimed mainly first. To find out what the functions of hedges are in Iraqi Arabic and this has been concluded throughout the study that is, Iraqi people use different types of hedges depending on the context and what is required in situations.

For example (it is reported that) most of the Iraqi people use this type of hedges when they want to express their opinions without taking the responsibility of what is said.

While, to the other types some are used to express uncertainty other are used to make things fuzzy or to leak the truth of the condition .... etc.

And according to the findings that have been reached by the researcher the hypothesis that Iraqi people use hedges a lot is confirmed. Second to identify the most common type used by people and also this has been concluded.

The type that is used by different Iraqi people is "plansibility shields" for example (as far as I know or I think) these hedges have reached the highest percentage which is $26 \%$ while some other types from shields hedges like (it would appear), or quadruple hedges like (it may appear somewhat 
speculative that) have not been mentioned in any of the twenty conversations and the percentage is $0 \%$. So the hypothesis that not all hedging types used frequently and there should be a specific type that is used most is confirmed.

\section{References:}

[1] Brown, p. And Levison s. (1978). Politeness some Universal in Language. in Language Usage Questions and politeness (56-289). Cambridge university press.

[2] ALGHAZALI, TAWFEEQ. "THE FUNCTIONS OF (INSHALLAH) GOD WILLING IN IRAQI DIALECT." International Journal of Mechanical and Production Engineering Research and Development (IJMPERD) 10.3, Jun 2020, 10569-10574

[3] Frasen, B. (2010). Pragmatic competence: the case of Hedging. in G. Kaltenbock, W. Mihatich\& S. Schnieder (Eds.). New Approaches to Hedging 1st ed. (pp. 15-34) Bingley, UK: Emerald Group publishing limited.

[4] Holmes. J (1982) Expressing Doubt and Certainty English R.E.L.C Johnalp.p.9-28 (1984) Hedging your bets Sitting on the Fence: some Hedges as support structures. Te Reo, 27:p.p 7-26.

[5] AMINO,

KAORU.

"CONCEPTUALIZING THE JAPANESE AND AMERICAN OCCUPATIONAL MEETING: AN EXAMINATION OF THE PRAGMATIC USAGE OF ENGLISH AND JAPANESE DISCOURSE MARKERS "OH” AND “ATT"." International Journal of Communication and Media Studies (IJCMS) 10.1, Feb 2020, 1-16

[6] Hubeler A. (1983). Pragmatic and Beyond: Understatementsand hedges in English Amsterdam john Benjamine publishing company.

[7] Hyland K.Hedging in scientific research Articles . Amsterdam and Philadelphia, PA:
PA: John Benjamin Publishing company, 1998.

[8] KANNAN, B. MARUTHU, and BG BARKI. "WEB ASSISTED COLLABORATIVE LEARNING TO TEACH DESIGN ENGINEERING-A PRAGMATIC APPROACH." Research and Development (IJAuERD) 3.2 (2013): 51-58.

[9] Lakkoff . G. (1972), Hedges A study of meaning Criteria and the logic of fuzzy concept . papers from the Eighth regional meeting (pp. 183-228) Chicago linguistic society. Lersen-freeman, D \& long M.H. (1991). An introduction to second language acquisition research. London: Longman.

[10] Lakoff, G, Hedges: A study in meaning criteria and the logic of fuzzy concepts . In P.Peranteau, J. Levi \&Phares (edg). Paper from eighth regional Meeting of the Chicago linguistic socity.1972.

[11] WULANDARI, RIZKA MAULINA. "AN ANALYSIS OF POLITENESS STRATEGIES IN EMAILS OF INDONESIAN EFL LEARNERS." International Journal of English and Literature (IJEL) 8.3, Jun 2018, 79-94

[12] Mayer p. (1997) Hedging strategic in written academic Discourse: strengthening the Argument by weakening the claim "In R..Markkanen and H.schroder (eds). Hedging and Discourse: Approaches to the analysis of apragmatic phenomenon in academic Texts (pp. 21-41) berlin: walter de gruitermousavi , s.A.1997.A dictionary of languageTesting. Shiraz Rahman publications.

[13] Myers: G (1989). The pragmatic of politeness in scientific Articles. Applied linguistics 10(1): pp.1-35.

[14] Prince .E.F.J frander\& C. Bock. On hedging in physician-physician discourse .in R.J. pietro (ed). Linguistics and the professions. New Jersey. Ablex, Norwood 1982. 
[15] Salagier- Meyer.F (2000). Procreates recipe: Hedging and Positivism "English for spatial purposes 19.pp. 195-187.

[16] Thompson, G (2000), Interaction in academic writing: learning to argue with the reader Applied linguistic voul. 22//.pp58-78 Tribile. C. (1996) writing oxford, oxford university press.
[17] Wills, W. (1997). Hedging in ExpertLanguage Review In. R. Markkanen and H.schorder (eds). Hedging and discourse: Approaches to the Analysis of a Pragmatic phenomenon.

[18] Yule, G.(2014) The Study of Language ( $5^{\text {th }}$ edition). Published in the united states of America by Cambridge university press. 